\title{
SEMIOCHEMICALS FROM FUNGAL ASSOCIATES OF BARK BEETLES MAY MEDIATE HOST LOCATION BEHAVIOR OF PARASITOIDS
}

\author{
BRIAN T. SULLIVAN's* and C. WAYNE BERISFORD ${ }^{2}$ \\ ${ }^{1}$ USDA Forest Service, Southern Research Station, 2500 Shreveport Highway \\ Pineville, Louisiana 71360, USA \\ ${ }^{2}$ Department of Entomology, University of Georgia, Athens \\ Georgia 30602, USA
}

(Received May 13, 2003; accepted November 25, 2003)

\begin{abstract}
In laboratory olfactometer bioassays, females of two hymenopteran parasitoid species, Roptrocerus xylophagorum (Ratzeburg) (Hymenoptera: Pteromalidae) and Spathius pallidus (Ashmead) (Hymenoptera: Braconidae), were attracted to odors from bark or bolts of loblolly pine, Pinus taeda L., colonized by bluestain fungi (genus Ophiostoma) associated with the parasitoids' bark beetle hosts. Mock-inoculated bolts and bark were less attractive or unattractive in these bioassays. Bark infested with host larvae that lacked their fungal and other normal microbial associates was attractive to $R$. xylophagorum females, but was less so than bark infested with larvae possessing their normal complement of associated microbes. In contrast, in oviposition bioassays, $R$. xylophagorum females spent approximately equal time searching, made similar numbers of oviposition attempts, parasitized similar percentages of hosts, and laid similar numbers of eggs in bark fragments infested with either associate-free or associate-bearing host larvae. Furthermore, in field bioassays using bluestaininoculated or mock-inoculated loblolly pine bolts as sources of attractants, the numbers of parasitoids attracted by the two treatments did not differ significantly and the two treatments were less attractive than bolts naturally infested with bark beetle larvae. Whereas our laboratory olfactometer data suggest that bark beetle fungal associates may enhance attraction of some parasitoids, our bioassays with associate-free hosts indicate that associate-produced are not required for shortrange host location and parasitization. In addition, our field trials indicated that long-range attraction of parasitoids to the host-fungi-tree complex is not caused simply by an interaction between bluestain fungi and tree tissues.
\end{abstract}

Key Words-Scolytidae, Pteromalidae, Braconidae, Pinus, Dendroctonus, Ips, parasitoids, host location, fungi, attraction, tritrophic, symbiosis.

*To whom correspondence should be. addressed. E-mail: briansullivan@fs.fed.us 
The mechanisms mediating host location by the guild of hymenopteran species that parasitize the larvae of bark beetles (Coleoptera: Scolytidae) are not completely understood (Bushing, 1965; Mills, 1983; Dahlsten and Berisford, 1995). Olfactory cues are clearly important (Kudon and Berisford, 198 1; Payne, 1989; Sullivan et al., 1997; Pettersson et al., 2001 b), but the chemical composition of the cues and their biological origins have been only partially characterized. Evidence suggests that an interaction between bark beetles and host tree phloem results in production of host location cues that are exploited by the parasitoids. Bark excised from healthy trees does not stimulate attraction or other host finding behaviors in bark beetle parasitoids, but will do so after infestation by bark beetle larvae (Samson, 1984; Mills et al., 1991; Sullivan et al., 2000). For several parasitoid species, infested bark remains attractive after removal of hosts, whereas isolated bark beetle larvae do not elicit parasitoid attraction, arrestment, or oviposition (Mills et al., 1991; Sullivan et al., 2000).

Bark beetles are closely associated with a variety of microorganisms, particularly fungi, which grow within the beetles' gallery systems and surrounding tree tissues, and are transported to new host trees during beetle dispersal (reviewed in Paine et al., 1997). Anecdotal and circumstantial evidence suggests that bark beetle-associated fungi might be sources of parasitoid host location cues (Dahlsten and Berisford, 199.5; Six and Dahlsten, 1999). Fungal symbionts of bark beetles possess qualities that make them potentially ideal indicators of host presence to parasitoids. Symbiotic fungi are closely associated with bark beetles in both time and space (Rumbold, 1931; Whitney, 1971; Bridges et al., 1984; Solheim, 1992), and the presence of preferred, late-instar beetle larvae within the bark coincides predictably with theabundanceofcertainfungi (Howeet al., 1971; Bridgeset al., 1984; Sullivan, 1997). In addition, fungi, including those associated with bark beetles, produce a range of volatile compounds either de novo or from precursors present in their environment, and these compounds or compound blends can be highly specific in their chemistry (Brand et al., 1977; Brand and Barras, 1977; Leufven et al., 1988; Hanssen, 1993). However, direct experimental evidence demonstrating a role for bark beetle-associated fungi in parasitoid host location is limited (Dahlsten and Berisford, 1995; Six and Dahlsten, 1999).

The purpose of this study was to investigate the possibility that fungal associates of bark beetles mediate host location by the beetles' parasitoids. We hypothesized that if fungal associates play this role, then (1) fungal associatecolonized tree tissue should stimulate parasitoid host-seeking in the absence of bark beetles, and, conversely, (2) elimination of microbial associates should inhibit parasitoid host location behaviors directed toward bark beetle hosts. Our laboratory tests of these hypotheses were performed largely with the parasitoid Roptrocerus xylophagorum (Ratzeburg) (Pteromalidae) because this species was 
available in large numbers and readily seeks and parasitises hosts in the laboratory. More than a dozen economically important species of bark beetle in North America and Europe are hosts for this wide ranging and abundant parasitoid (Sullivan et al., 2000). R. xylophagorum prefers late-instar larval hosts but also parasitises pupae (Samson, 1984). Tests of parasitoid attraction to fungicolonized tree tissue were performed exclusively with the beetles' bluestain associates (order Ophiostomatales) because of their reliable association with bark beetles (Upadhyay, 1981) and their ability to grow relatively rapidly into tree tissues in the absence of insects (Bramble and Holst, 1940; Paine and Stephen, 1987).

\section{METHODS AND MATERIALS}

Insectsfor Laboratory Assays. R. xylophagorum were obtained from a laboratory colony maintained for several generations on bolts of loblolly pine, Pinus taedu L., artificially infested with the southern pine engraver, Ips grandicollis (Eichhoff) (Sullivan et al., 1999). Spathius pallidus (Ashmead) (Braconidae) females were collected as they emerged from loblolly pine bolts infested by the southern pine beetle, Dendroctonus frontalis Zimmermann, and/or Ips spp. bark beetles. Parasitoids and beetles were originally obtained in Louisiana, Georgia, Alabama, and Mississippi. After emergence, parasitoids were maintained in mixed-sex groups within $250 \mathrm{ml}$ Erlenmeyer flasks held at $8 \pm 1^{\circ} \mathrm{C}$ with a 14: 10 (L:D) hr light regime and were provided honey and water. Assayed R. xylophagorum were 5-7 day old; S. pallidus were 2-24 day old.

Fungi. Pure cultures of the bluestain fungi Ophiostoma minus (Hedgcock) H. \& P. Sydow and Ophiostoma ips (Rumbold) Nannfeldt were obtained from perithecia within pine bark infested with either D. jirontalis or I. grandicollis, respectively, and were maintained on phloem-strip agar (2\% agar and loblolly pine phloem, autoclaved) slants in $50 \mathrm{ml}$ screw-top culture tubes. Slants were incubated at $23-27^{\circ} \mathrm{C}$ until sporulating perithecia were observed. Inoculum consisted of sterile, distilled water $(7-8 \mathrm{ml})$ swirled gently inside these slant tubes for several minutes.

Bolt Inoculations. Bolts ( $30-50 \mathrm{~cm}$ long, $13-25 \mathrm{~cm}$ diam) were cut with an ethanol-sterilized bow saw from a live loblolly pine, and the ends were coated with a $2 \%$ solution of sorbic acid and methyl paraben to retard mold growth. The outer, corky bark was shaved to remove loose bark flakes, sprayed to saturation with $70 \%$ ethanol, and allowed to dry. Bolts were inoculated by removing disks of bark (14 mm diam), placing a drop of inoculum on the exposed sapwood, replacing the disks, and covering them with masking tape. Inoculation points were spaced $5 \mathrm{~cm}$ apart circumferentially and $1.5 \mathrm{~cm}$ apart lengthwise. Bolts were incubated at $21-29^{\circ} \mathrm{C}$ and $50-70 \% \mathrm{RH}$. 
For both the field trapping experiment and flight tunnel bioassay, the above procedure was modified slightly. Longer bolts (1-2 m) were used, and inoculum ( $\sim 1 \mathrm{ml})$ was applied evenly to saw-cuts $(2 \mathrm{~mm}$ wide) that encircled the bolts and lightly scored the sapwood. The saw-cuts were made with an ethanol-sterilized pruning saw every $35 \mathrm{~cm}$ along the bolts and, following inoculation, were covered by masking tape. This inoculation technique resulted in a more complete fungal colonization of the bolts than the bark disk method.

Associate-Free Hosts. Studies on the effects of elimination of bark beetle associates on parasitoid host location were conducted with 1. grandicollis because this species can develop normally without its usual microbial associates (Yearian et al., 1972). Eggs of I. grandicollis were surface-sterilized in improved White's solution (Barras, 1972), rinsed repeatedly in sterile-distilled water, and allowed to hatch on moistened, autoclaved filter paper in Petri dishes. Individual, newlyhatched larvae ( $\leq 1$ day old) were transferred to an artificial "niche" $\left(1 \mathrm{~mm}^{3}\right)$ cut into the phloem of a bark "sandwich." Bark sandwiches consisted of freshly excised pieces of loblolly pine bark $(3 \times 7 \mathrm{~cm})$ with the exposed phloem surface pressed to a clean, sterile microscope slide $(5 \times 7.5 \mathrm{~cm})$ (Sullivan et al., 2000). Bark for sandwiches are excised with sterile implements from bolts that had been shaved and sprayed with ethanol as described above. Sandwiches were infested with up to 10 larvae and then incubated at $29^{\circ} \mathrm{C}$ and $-80 \% \mathrm{RH}$ until larvae reached the third instar. Aseptic technique was used for all steps in the preparation and handling of eggs, larvae, and bark sandwiches.

$Y$-Tube Bioassays with $R$. xylophagorum. We assayed the anemotaxis of walking female $R$. xylophagorum in a Y-tube olfactometer described in detail elsewhere (Sullivan et al., 2000). Individual females were released into the stem of a glass Y (4 mm i.d., stem $4 \mathrm{~cm}$, branches $5 \mathrm{~cm}$ and 135 " to the stem) with each branch receiving air $\left(30 \mathrm{ml} / \mathrm{min}, 25-27^{\circ} \mathrm{C}\right.$ and $\left.50-70 \% \mathrm{RH}\right)$ from a different sample holding tube. A parasitoid was recorded as choosing an odor source when it walked $3 \mathrm{~cm}$ into the associated olfactometer branch. Parasitoids that failed to make a choice during $5 \mathrm{~min}$ were recorded as nonresponders. The assignment of odor sources to each branch was reversed and Y-tubes were replaced with clean ones after each trial. Individual parasitoids were tested only once.

The first experiment tested female attraction to bark rectangles $(3 \times 7 \mathrm{~cm}$, both phloem and corky bark) excised from bolts inoculated 2-3 wk earlier with 0. ips. Bark rectangles were cut lengthwise with the grain and centered over the inoculation sites, but did not include the replaced bark disks. 0. ips was chosen as the inoculum for this test because it is the bluestain fungus associated with I. grandicollis, the host on which the bioassayed $R$. xylophagorum were reared. A sterile, "mock" inoculum was produced by passing the culture rinsate inoculum through a $0.2 \mathrm{pm}$-mesh syringe filter to remove microbial propagules. Parasitoids were given three binary choices (replicated x 36): (A) 0. ips-inoculated bark versus 
clean air, (B) mock-inoculated bark versus clean air, and(C) 0. @ s-inoculated bark versus mock-inoculated bark.

The second experiment tested odors from bark sandwiches infested with 10 third instar I. grundicollis that were either associate-free or obtained from naturally infested bolts and, thus, presumably had their normal compliment of microbial associates ("unaltered" larvae). Infested bark sandwiches were incubated 3 day at $29^{\circ} \mathrm{C}$ and $70-80 \% \mathrm{RH}$ before assays. Parasitoids were given three binary choices (replicated $\mathrm{x} 44$ ): (A) bark sandwiches with unaltered larvae versus clean air, (B) bark sandwiches with associate-free larvae versus clean air, and (C) bark sandwiches with unaltered larvae versus bark sandwiches with associate-free larvae. In both Y-tube experiments, component tests were balanced for day, time of day, and tree (bolts/bark were derived from up to three different trees).

A significant preference for one olfactometer branch was identified with the Gtest for goodness-of-fit or, when fewer than 25 insects responded, by determining the probability of the observed outcome from a table of cumulative binomial probabilities assuming a null hypothesis of no preference (Sokal and Rohlf, 1995).

Close-Range Host Search and Oviposition Assay with R. xylophagorum. Pairs of bark sandwiches were infested with an identical number (5-10/sandwich) of either associate-free or unaltered third instar 1. grundicollis larvae, incubated for 3 days at $29^{\circ} \mathrm{C}$, and tested in random order in a double-blind bioassay. The microscope slide was removed from each sandwich, and the bark was placed phloem side-up in a $10 \mathrm{~cm}$ diam glass Petri dish with a single female $R$. xylophagorum. A piece of filter paper on the exposed phloem surface concealed any visual host cues. During $15 \mathrm{~min}$, we recorded the number of times the female inserted her ovipositor into the filter paper (considered a single oviposition attempt) and the total time she spent searching on the bark. Observations were performed consecutively with three different females and the same sandwich/dish, and then all three females were placed into the dish at once and allowed to host-search and oviposit undisturbed for $-90 \mathrm{~min}$. Afterward, the bark pieces were dissected and examined for percent parasitization of the host larvae, and the number of eggs laid per host. The experiment was replicated $\mathrm{x} 5$ and analyzed with a Wilcoxon signed-rank test. Samples of phloem and frass from ail infested sandwiches were plated on $2 \%$ malt agar and incubated at room temperature for 4-12 days.

Field Trapping. Parasitoid attraction to bolts inoculated with 0 . minus, the bluestain associate of $D$. frontalis, was tested within active $D$. frontalis infestations. Bolts were divided into $30-35 \mathrm{~cm}$ long sections, and four evenly-spaced vertical strips ( $3 \mathrm{~cm}$ wide) of bark were removed from each to approximate the phloem damage and air-exposure produced by bark beetle mines. Five bait treatments were compared: a bolt section inoculated with 0 . minus and incubated either 3-4 wk (1) or 5-6 wk (2), a bolt section inoculated with sterile, distilled water ("mock" "-inoculated) and incubated either 3-4 wk (3) or 5-6 wk (4), and a bolt (30$35 \mathrm{~cm}$ long) from a loblolly pine infested with late larval instars of $D$. frontalis (5). 
An unbaited stovepipe (30 $\mathrm{cm}$ long, $20 \mathrm{~cm}$ diam) served as a "semiochemical-free" control. Bolts and stovepipes were erected on $2 \mathrm{~m}$-high metal posts, covered by a bag of fine-mesh nylon screen (to prevent beetle attacks and provide a uniform visual appearance among treatments), and then surrounded by a cylinder $(30 \mathrm{~cm}$ high, $25 \mathrm{~cm}$ diam) of $1.3 \mathrm{~cm}$-mesh plastic hardware cloth coated with Stikem Special@ (Seabright Laboratories, Emeryville, CA). Traps were arranged in randomized complete blocks, with traps spaced $>3 \mathrm{~m}$ apart within blocks, $>5 \mathrm{~m}$ apart between blocks, and $>1.5 \mathrm{~m}$ from any tree. Blocks of traps were erected in the early afternoon (2-3 at one time), and screens were collected and bolts discarded after $24 \mathrm{hr}$. Eleven replicates were completed in the Homochitto National Forest, Mississippi, between 25 June and 25 July 2002. Raw catch of parasitoid females was transformed with $\log _{10}(X+1)$ to remove heteroscedasticity and analyzed with a two-way analysis of variance (with block and treatment as factors) and the Student-Newman-Keuls (SNK) test for all-pairwise comparisons.

Flight Tunnel Bioassay with $S$. pallidus. We compared the relative attractiveness of 0 . minus- and mock-inoculated pine bolts to the parasitoid $S$. pallidus in a plate glass flight tunnel ( $40 \times 40 \times 100 \mathrm{~cm}$ long). The tunnel was operated in a greenhouse $\left(29-35^{\circ} \mathrm{C}\right.$ and $\left.50-75 \% \mathrm{RH}\right)$ with natural light filtered through a white cloth canopy $(2,500-10,000 \mathrm{~lx})$ and an air speed of $1 \mathrm{~m} / \mathrm{sec}$. Fifteen female $S$. pallidus were released from a screen box placed $75 \mathrm{~cm}$ downwind from a vertical test bolt $(30 \mathrm{~cm}$ long), and the number of individuals exhibiting oriented flight and landing on the bolt during 20 min was recorded. Bolts inoculated 5-6 wk previously with either 0 . minus or sterile distilled water were alternated between trials. Each treatment was replicated 6-7 times, and results were analyzed with a MannWhitney rank sum test. All statistical analyses were performed using SigmaStat $^{\mathrm{TM}}$ 2.03 software (SPSS, 1997), and an alpha level of 0.05 was used in all tests.

\section{RESULTS}

Response of R. xylophagorum to Bark Colonized by 0. ips. Fifty to eighty percent of the phloem in bark rectangles excised from 0 . ips-inoculated bolts was stained black or appeared necrotic, whereas phloem from the mock-inoculated bolts was white and apparently healthy except within 1-2 mm from inoculation points. In Y-olfactometer assays, bark rectangles from 0 . ips-inoculated bolts were attractive to female $R$. xylophagorum, whereas those from the mock-inoculated bolts were not (Figure 1). When exposed to both simultaneously, female $R$. $x y$ lophagorum showed a strong preference for bark from 0 . ips-inoculated bolts over that from mock-inoculated bolts.

Response of R. xylophagorum to Associate-Free Hosts. No bacteria, yeasts, or bluestain fungi were cultured from 88 samples of frass and phloem from 16 bark sandwiches infested with associate-free I. grandicollis larvae. Seven of the 


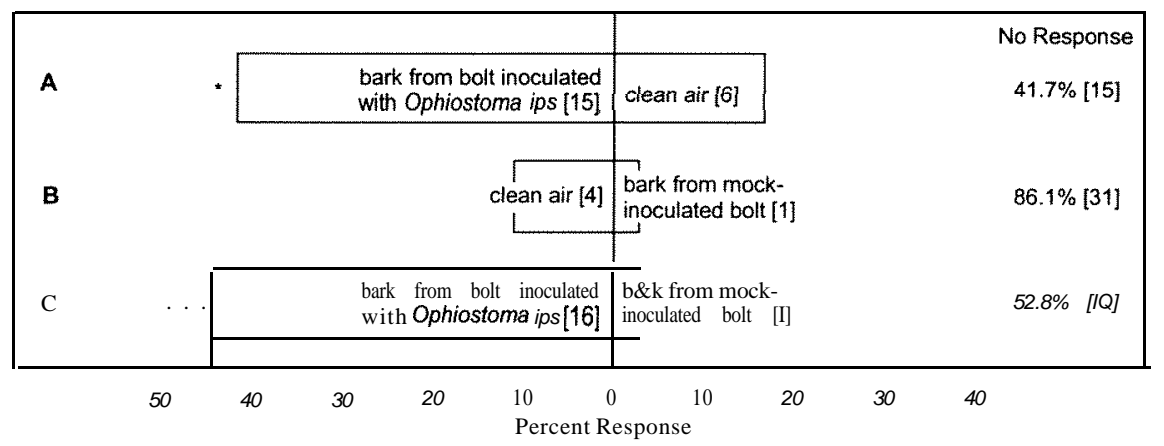

FIG. 1. Responses by individual Roptrocerus xylophagorum females in a Y-olfactometer to bark excised from loblolly pine bolts inoculated 2-3 wk previously either with the bluestain fungus, Ophiostoma ips, or filter-sterilized 0. ips inoculum. Raw numbers of insects responding/not responding are shown in brackets. Asterisks indicate a significant preference for that treatment $\left({ }^{*} P<0.05 ;{ }^{* * *} P<0.001\right)$.

samples (six sandwiches) contained mycelial fungi that were either saprophytes of the corky bark of pines (DeHoog and Morgan-Jones, 1978), common molds (e.g., Penicillium spp.), or fungi otherwise not typically recognized as beetle associates. In contrast, all 15 sandwiches infested with unaltered beetle larvae were colonized by yeasts and/or bacteria (all 83 samples cultured) and 0. ips ( 75 of 83 samples). Six of fifteen sandwiches infested with unaltered beetle larvae also had Trichoderma spp. present. Survival of $I$. grandicollis in bark sandwiches during the 3 day incubations was similar for both treatments $(87.5 \pm 4.1 \% \mathrm{SE}$ for associate-free versus $80.6 \pm 4.8 \%$ for unaltered larvae; $t_{(12,13)}=138.0, P=0.34$, Mann-Whitney test), as was the apparent rate of development evidenced by the percentage that molted to pupae $(30.9 \pm 5.4 \%$ for associate-free versus $24.3 \pm 5.4 \%$ for unaltered larvae; $t_{(12,13)}=141.5, P=0.45$, Mann-Whitney test).

Bark infested with either associate-free or unaltered larvae of I.grundicollis was attractive to female $R$. xylophagorum in the Y-olfactometer (Figure 2). However, $R$. xylophagorum showed a strong preference for bark infested with unaltered larvae over bark infested with associate-free larvae. When allowed contact with the bark, $R$. xylophagorum females spent roughly equal time searching and made similar numbers of oviposition attempts on bark infested either with associate-free or unaltered hosts (Table 1). There were also no significant differences between the treatments in either percentages of parasitized hosts or the number of eggs laid per host.

Field Response of Parasitoids to Bolts Inoculated with 0. minus. Approximately $80-100 \%$ of the phloem/sapwood interface on bolts inoculated with 0 . minus either 3-4 or 5-6 wk previously was covered by dark stain and perithecia of this fungus. Cross sections of these bolts revealed extensive penetration of stain 


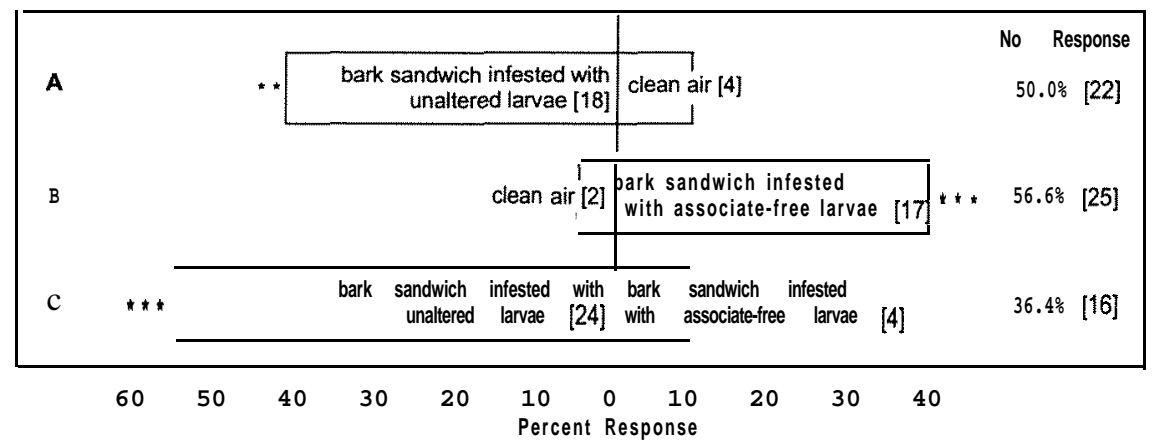

FIG. 2. Responses by individual Roptrocerus xylophagorum females in a Y-olfactometer to bark sandwiches infested artificially with third instar I ps grandicollis larvae that were either obtained from a naturally infested pine bolt (and ostensibly possessed their normal microbial associates) or reared from surface-sterilized eggs (and thus lacked associates). Raw numbers of insects responding/not responding are shown in brackets. Asterisks indicate a significant preference for that treatment $\left({ }^{* *} P<0.01 ;{ }^{* * *} P<0.001\right)$.

into the sapwood. In contrast, the phloem and sapwood of mock-inoculated bolts generally appeared healthy, and discoloration and other evidence of necrosis were minimal or absent. Total catch of $\mathbf{D}$. frontalis parasitoids was significantly greater at traps baited with either 5-6-wk-old 0 . minus-inoculated bolts or host-infested bolts, than unbaited stovepipe traps $(\mathrm{P}=0.004$ and $\mathbf{P}<0.001$, respectively, SNK test) (Figure 3). However, 0. minus-inoculated bolts did not catch significantly more parasitoids than mock-inoculated bolts incubated the same length of time. When parasitoid species were analyzed individually, S. pallidus was the only species caught in greater numbers on an inoculated bolt treatment (i.e., 5-6-wkold 0. minus-inoculated) than on the unbaited controls $(\mathbf{P}=\mathbf{0 . 0 3 3}$, SNK test),

Table 1. Host Searching and Oviposition Responses of Female Roptrocerus xylophagorum to BARK S ANDWiches InfESTED 3 DaYs PREVIOUSLY with ThiRd INSTAR LARvae of ms Host, Ips grandicollis

\begin{tabular}{lcc}
\hline & Axenic host larvae & Untreated host larvae \\
\hline Live hosts e isandwich & $8.0 \pm 0.9$ & $7.2 \pm 0.9$ \\
Ratio pupal/larval hosts & $0.27 \pm 0.05$ & $0.45 \pm 0.22$ \\
Search time (min)" & $7.7 \pm 1.9$ & $7.0 \pm 1.7$ \\
Oviposition attempts" & $2.9 \pm 0.7$ & $2.5 \pm 0.8$ \\
Percent parasitization (all hosts) & $54.7 \pm 9.9$ & $50.0 \pm 6.6$ \\
Percent parasitization (larvae) & $66.6 \pm 14.0$ & $71.9 \pm 12.1$ \\
Eggs per host & $\mathbf{1 . 3 0 1 t o . 1 1}$ & $1.60 \pm 0.04$ \\
\hline
\end{tabular}

a Mean female response per bark sandwich. 


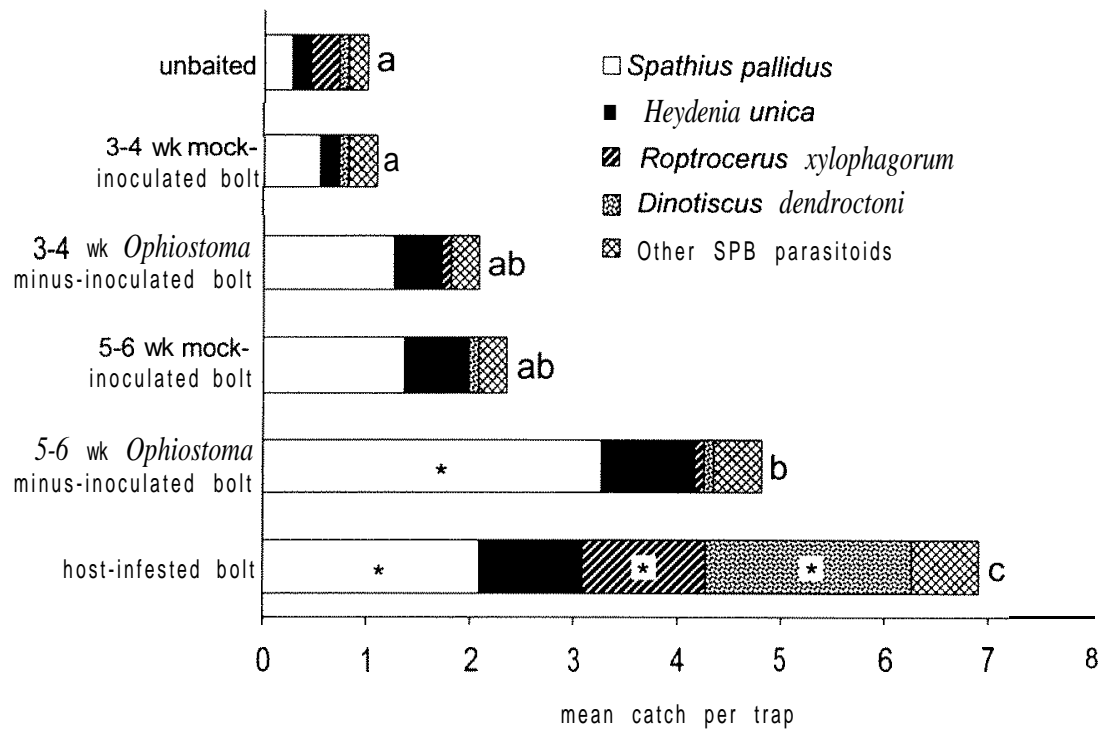

FIG. 3. Responses of female pdrasitoids of Dendroctonus frontalis to sticky traps placed within an active $D$. frontalis infestation. Traps were baited with loblolly pine bolts that had been either inoculated with 0 . minus (the bluestain fungus associated with $D$. front \&s), inoculated with sterile distilled water ("mock-inoculated"), or infested naturally with lateinstar D. frontalis larvae. Fungus- and mock-inoculated bolts had been incubated at $2 \mathrm{I}-29^{\circ} \mathrm{C}$ for either 3-4 or S-6 wk. "Other SPB parasitoids" included Coeloidespissodis, Dendrosoter sulcatus, Eurytoma tomici, and Eupelmus sp. Treatments associated with the same letter were not significantly different in catch of all $D$. frontalis parasitoids $(\mathrm{a} !=0.05)$. Asterisks indicate when an individual parasitoid species was attracted to a particular bait treatment in significantly greater numbers than to the unbaited control trap.

and no species was trapped in higher numbers on fungus-inoculated bolts than mock-inoculated bolts. Three species, S. pallidus, R. xylophagorum, and Dinotiscus dendroctoni (Ashmead) (Pteromalidae), were attracted to D.frontalis-infested bolts in greater numbers than the unbaited controls. Other hymenopteran parasitoids of D. frontalis trapped in small numbers included Heydenia unica Cook and Davis (Pteromalidae), Coeloides pissodis (Ashmead) (Braconidae), Dendrosoter sulcatus Muesbeck (Braconidae), Eurytoma tomici Ashmead (Eurytomidae), and Eupelmus sp. (Eupelmidae).

Flight Tunnel Response by S. pallidus to 0. minus-Inoculated Bolts. In the flight tunnel, a significantly higher percentage of $S$. pallidus females were stimulated to fly upwind and alight on 5-6-wk-old bolts inoculated with 0 . minus than mock-inoculated bolts of the same age $\left(t_{(6,7)}=59.5, P=0.008\right)$ (Figure 4). 


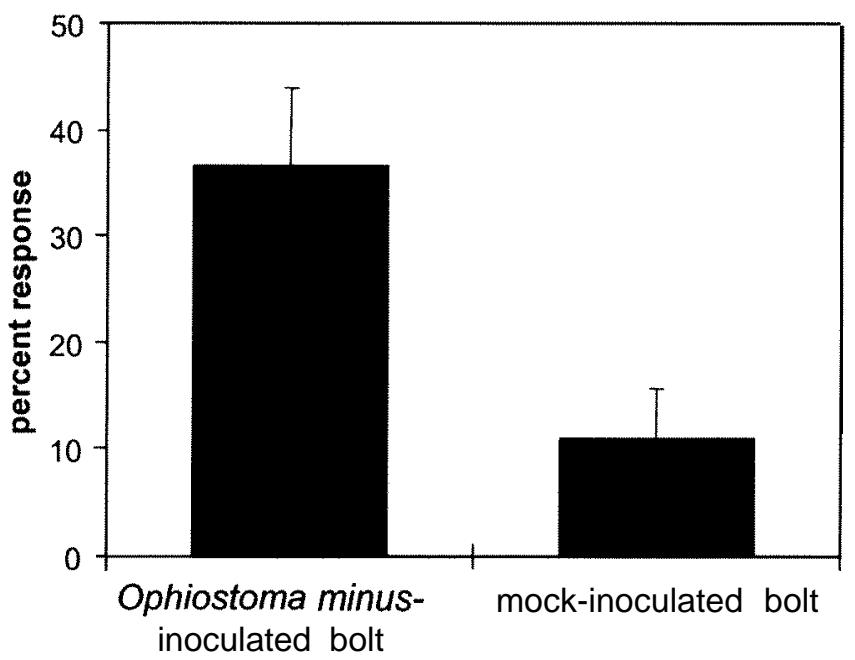

FIG. 4. Percentage of Spathius pallidus females responding in single-choice flight tunnel tests to loblolly pine bolts inoculated $5-6 \mathrm{wk}$ previously with either 0 . minus or sterile distilled water. Responding females flew toward and landed on vertically oriented bolts positioned $75 \mathrm{~cm}$ upwind from the parasitoids' release point. Responses to the two treatments were significantly different $(P=0.008$, Mann-Whitney rank sum test).

\section{DISCUSSION}

Results from the laboratory bioassays suggested that bole tissue of loblolly pines produced semiochemical attractants for two bark beetle parasitoids, $R$. $x y$ lophagorum and S. pallidus, after inoculation with the bluestain fungi 0 . ips and 0 . minus, respectively. In light of the close association between these fungi and hosts of the parasitoids, the results suggest that olfactory cues produced by bluestain fungi may provide at least some of the cues that $R$. xylophagorum and $S$. pallidus use to locate host habitats. Parasitoids of other insects, notably siricid woodwasps and drosophilid and tephritid fruit flies, also have been shown to respond to semiochemical cues produced by microbial associates of their hosts (Madden, 1968; Spradberry, 1970; Dicke, 1988; Thibout et al., 1993). Natural selection tends to favor adaptations in hostinsects that reduce apparency to parasitoids (Vet et al., 1991), and such selective pressures may explain the apparent lack of host location cues produced by bark beetle larvae isolated from tree tissue (Mills et al., 1991; Sullivan et al., 2000). In contrast, microbial symbionts of bark beetles are under no direct selective pressure to limit their apparency to the beetles' natural enemies, hence cues arising from the host's symbionts may serve as sumogates for host-produced cues. 
Some symbionts of bark beetles, particularly the bluestain fungi, reduce the fitness and survival of bark beetle broods by competing directly with the beetles for nutrients or otherwise rendering bark unsuitable for brood development (Barras, 1970; Yearian et al., 1972; Fox et al., 1993; Six and Paine, 1998). Our data suggest the possibility that these fungi may reduce brood survival further by attracting natural enemies of beetle larvae.

However, cues from microbial associates of I. grandicollis were not necessary for short-range host location and parasitization by $R$. xylophagorum, suggesting that associate-generated attractants might play a restricted or unessential role in mediating these behaviors. In laboratory bioassays, bark infested with I. grandicollis larvae that lacked the normal complement of microbial associates still stimulated attraction, arrestment, ovipositor drilling, and oviposition by $R$. xylophagorum. Nonetheless, in the Y-olfactometer, $R$. xylophagorum showed a strong preference for bark infested by associate-bearing larvae over bark infested with associate-free larvae. In combination, these results suggest that cues from host-associated microbes are not essential for successful host finding, but nevertheless may enhance host detectability or otherwise influence host location by $R$. xylophagorum.

In the field experiment, parasitoids failed to discriminate between bluestainand mock-inoculated bolts, and bluestain-colonized bolts were less attractive than host-colonized bolts. This suggests that long-range host location cues arising from the host-fungi-tree complex are not produced simply by an interaction between bluestain fungi and tree tissues. $R$. xylophagorum's apparent lack of attraction in field tests to pine bole tissue colonized by the bluestain fungus 0 . minus contrasted with their attraction in Y-olfactometer tests to tissue colonized by another bluestain fungus, 0. ips. This was unexpected given that these fungi are similar in biology and both are associated with hosts for $R$. xylophagorum. Flying $R$. xylophagorum may not respond to bluestain-associated odors the same as walking individuals, or odors from excised, bluestain-colonized bark (used in the 0. ips tests) may produce a different response than odors from whole, bluestain-colonized bolts (used in the 0. minus tests). Alternatively, in the Y-tube bioassays, the wasps were presented with a limited number of stimuli to which they could respond, whereas in bioassays run under field conditions, wasps were presented with a plethora of olfactory, visual, and tactile sensory inputs.

In the present study, parasitoid-attracting semiochemicals may have been produced by tissue of the fungus itself or, alternatively, by tree tissue in response to fungal infection. Bark beetle-associated fungi produce a variety of distinctive compounds when grown in pure culture (Brand et al., 1977; Brand and Barras, 1977; Leufven et al., 1988; Hanssen, 1993). In addition, infection of conifers by a variety of bark beetle-associated fungi (particularly Ophiostoma spp.) generates blends of volatiles in the surrounding tissue that differ quantitatively and qualitatively from those associated with healthy tissue (Russell and Berryman, 1976; Raffa and Berryman, 1982; Cook and Hain, 1985; Paine et al., 1987; Raffa and 
Smalley, 1995). Studies on the chemistry of the host location cues of bark beetle parasitoids have demonstrated the importance of a group of approximately 7-15 cyclic monoterpene alcohols, ketones, and aldehydes. These oxygenated monoterpenes are consistently associated with conifer tissues infested with bark beetle larvae (Birgersson et al., 1992; Sullivan et al., 2000; Pettersson, 2001b), elicit strong antennal responses from several parasitoids of conifer-infesting bark beetles (Salom et al., 1991, 1992; Pettersson et al., 2000, 2001a,b; Pettersson, 2001a), and, in various combinations, are attractive to female parasitoids (Pettersson, 2001a; Pettersson et al., 2000, 2001a). Necrotic phloem surrounding sites on pine bolts inoculated with 0 . minus or 0 . ips contain elevated levels of 6-8 of these oxygenated monoterpenes (Sullivan, 1997), and bark beetle-associated yeasts and mycelial fungi grown in pure culture with conifer-derived substances also produce some of these compounds (Leufven et al., 1988; Sullivan, 1997). Hence, bark beetleassociated fungi may elicit parasitoid attraction by increasing the concentrations ofparasitoid-attracting oxygenated monoterpenes within tree tissues colonized by bark beetles.

Acknowledgments - The authors are grateful for technical assistance provided by Katja Seltmann, Mark Dalusky, Richard Garland, Jonny Fryar, Aftan Walker, Jamie Dubois, and Jenny Gavilanez-Slone. Claes Johansson assembled our flight tunnel. We also thank the University of Georgia Experimental Forest, Whitehall, and Supervisor Mike Hunter for supplying us with healthy pines. Critical readings of the original manuscript were provided by Ken Raffa and Diana Six.

\section{REFERENCES}

BaRRas, S. J. 1970. Antagonism between Dendroctonus frontalis and the fungus Ceratocystis minor. Ann. Entomol. Soc, Am. 63:1187-1190.

BARRAS, S. J. 1972. Improved White's solution for surface sterilization of pupae of Dendroctonus frontalis. J. Econ. Entomol. 65: 1504.

Birgersson, G., Dalusky, M. J., Espelie, K. E., and Berisford, C. W. 1992. Isolation and identification of kairomones utilized by southern pine beetle parasitoids, p. 30, in D. C. Allen and L. P. Abrahamson (eds.). Proceedings: North American Forest Insect Work Conference, 25-28 March 1991, Denver, Colorado. USDA Forest Service Gen. Tech. Rpt. PNW-GTR-294.

BRAMBLE, W. C. and HOLST, E. C. 1940. Fungi associated with Dendroctonus frontalis in killing shortleaf pines and their effect on conduction. Phytopathology 30:881-899.

BRAND, J. M. and BARRAS, S. J. 1977. The major volatile constituents of a Basidiomycete associated with the southern pine beetle. Lloydia 40:398-400.

Brand, J. M., Schultz, J., Barras, S. J., Edson, L. J., Payne, T. L., and Hedden, R. L. 1977. Enhancement of Dendroctonus frontalis (Coleoptera: Scolytidae) aggregation pheromone by yeast metabolites in laboratory bioassays. J. Chem. Ecol. 3:657-666.

Bridges, J. R., MARLER, J. E., and MCSparrin, B. H. 1984. A quantitative study of the yeasts and bacteria associated with laboratory-reared Dendroctonus frontalis Zimm. (Coleopt.: Scolytidae). J. Appl. Entomol. 97:261-267.

BusHinG, R. W. 1965. A synoptic list of the parasites of Scolytidae (Coieoptera) in North America north of Mexico. Con. Entomol. 97:449-492. 
Co0K, S. P. and HAIN, F. P. 1985. Qualitative examination of the hypersensitive response of loblolly pine, Pinus taeda L., inoculated with two fungal associates of the southern pine beetle, Dendroctonus frontalis Zimmermann (Coleoptera: Scolytidae). Environ. Entomol, 14:396-400.

DAHLSTEN, D. L. and BERISFORD, C. W. 1995. Diversity of bark beetle natural enemies, pp. 184-201, in F. P. Hain, S. M. Salom, W. F. Ravlin, T. L. Payne, and K. F. Raffa (eds.). Behavior, Population Dynamics, and Control of Forest Insects: Proceedings of the International Union of Forestry Research Organizations, Joint Conference, 6-1 1 February 1994, Maui, Hawaii.

DEHOOG, G. S. and Morgan-Jones, G. 1978. Notes on Hyphomycetes. XXIII. Paraphaeosaria alahamensis gen. et sp. nov. Mycotaxon 7:133-138.

DICKE, M. 1988. Microbial allelochemicals affecting the behavior of insects, mites, nematodes, and protozoa in different trophic levels, pp. 125-163, in P. Barbosa and D. K. Letoumeau (eds.). Novel Aspects of Insect-Plant Interactions. Wiley, New York.

Fox, J. W., Wood, D. L., Akers, R. P., and PARMETER, J. R., Jr. 1993. Survival and development of Ips paraconfusus Lanier (Coleoptera: Scolytidae) reared axenically and with tree-pathogenic fungi vectored by cohabitating Dendroctonus species. Can. Entomol, 125: 1157-1 167.

HANSSEN, H. P. 1993. Volatile metabolites produced by species of Ophiostoma and Ceratocystis, pp. 117-126, in M. J. Wingfield, K. A. Seifert, and J. F. Webber (eds.). Ceratocystis and Ophiostoma. APS Press, St. Paul, MN.

Howe, V. K., Oberle, A. D., Keeth, T. G., and Gorwn, W. J. 1971. The role of microorganisms in the attractiveness of lightning-struck pines to southern pine beetles. Western Illinois University Series in the Biological Sciences No. 9.

KUDON, L. H. and BERISFORD, C. W. 1981. An olfactometer for bark beetle parasites. J. Chem. Ecol. $7: 359-366$.

Leufven, A., Bergstrom, G., and Falsen, E. 1988. Oxygenated monoterpenes produced by yeasts, isolated from, Ips typographus (Coleoptera: Scolytidae) and grown in phloem medium. J. Chem. Ecol. 14:353-362.

Madden, J. L. 1968. Behavioral responses of parasites to the symbiotic fungus associated with Sirex noctilio, Nature 2 18: 189.

Mills, N. J. 1983. The natural enemies of scolytids infesting conifer bark in Europe in relation to biological control of Dendroctonus spp. in Canada. Biocontrol News Inf. 4:305-328.

Mills, N. J., KRUger, K., and SChluP, J. 1991. Short-range host location mechanisms of bark beetle parasitoids. J. Appl. Entomol. 111:33-43,

Paine, T, D., Blanche, C. A., Nebeker, T, E., and Stephen, F. M. 1987. Composition of loblolly pine resin defenses: Comparison of monoterpenes from induced lesion and sapwood resin. Can. J. Forest Res, 17: 1202-1 206.

PAINE, T. D., RAFFA, K. F., and HARRINGTON, T. C. 1997. Interactions among scolytid bark beetles, their associated fungi, and live, host conifers. Annu. Rev. Entomol. 42: 179-206.

PaIne, T. D. and Stephen, F. M. 1987. Fungi associated with the southern pine beetle: Avoidance of induced defense response in loblolly pine. Oecologia 74:377-379.

PAYNE, T. L. 1989. Olfactory basis for insect enemies of allied species, pp. 55-69, in D. L. Kulhavy and M. C. Miller (eds.). Potential for Biological Control of Dendroctonus and Ips Bark Beetles. University of Texas Press, Austin, TX.

PETtersson, E. M. 2001a. Volatile attractants for three Pteromalid parasitoids attacking concealed spruce bark beetles. Chemoecology 11:89-95.

PetTersson, E. M. 2001b. Volatiles from potential hosts of R hopalicus tutela, a bark beetle parasitoid. J. Chem. Ecol. 27:2219-2231.

PETtersson, E. M., Birgersson, G., and WITZGAlL, P. 2001 a. Synthetic attractants for the bark beetle parasitoid Coeloides bostrichorum Giraud (Hymenoptera: Braconidae). Naturwissenschajien $88: 88-91$. 
Pettersson, E. M., HAllberg, E., and Birgersson, G. 2001b. Evidence for the importance of odourperception in the parasitoid Rhopulicus tutela (Walker) (Hym., Pteromalidae). J. Appl. Entomol. 125:293-301.

Pettersson, E. M., Sullivan, B. T., Anderson, P., Berisford, C. W., and Birgersson, G. 2000. Odor perception in the bark beetle parasitoid Roptrocerus xylophagorum exposed to host associated volatiles. J. Chem. Ecol, 26:2507-2525.

RAFFA, K. F. and BerRymAn, A. A. 1982. Accumulation of monoterpenes and associated volatiles following inoculation of grand fir with a fungus transmitted by the fir engraver, Scolytus ventralis (Coleoptera: Scolytidae). Can, Entomol. 114:797-810.

RAFFA, K. F. and SMALlEY, E. B. 1995. Interaction of pre-attack and induced monoterpene concentrations in host conifer defense against bark beetle-fungal complexes. O ecologiu 102:285-295.

RUMBOLD, C. T. 1931. Two blue-staining fungi associated with bark-beetle infestation of pines. J. Agric. Res. 43:847-873.

Russell, C. E. and Berryman, A. A. 1976. Host resistance to the fir engraver beetle. 1. Monoterpene composition of Abies grandis pitch blisters and fungus-infected wounds. Can. J. Bot. 54: 14-18.

Salom, S. M., Ascoli-Christensen, A., Birgersson, G., Payne, T. L., and Berisford, C. W. 1992. Electroantennogram responses of the southern pine beetle parasitoid Coeloides pissodis (Ashmead) (Hym., Braconidae) to potential semiochemicals. J. Appl. Entomol. 114:472-479.

Salom, S. M., Birgersson, G., PAyne, T. L., and Berisford, C. W, 1991. Electroantennogram responses of the southern pine beetle parasitoid Dinotiscus dendroctoni (Ashmead) (Hymenoptera: Pteromalidae) to potential semiochemicals. J. Chem. Ecol. 17:2527-2538.

SAMSON, P. R. 1984. The biology of Roptrocerus xylophagorum (Hym.:Torymidae), with a note on its taxonomic status. Entomophaga 29:287-298.

SiX, D. L. and DAHLSTEN, D. L. 1999. Interactions of bark beetle natural enemies and beetle-associated fungi, pp. 41-43, in E. M. Goheen (ed.). Proceedings of the Fifth Joint Meeting of the Western International Forest Disease Work Conference and Western Forest Insect Work Conference, 13-17 September 1999, Breckenridge, CO.

SIX, D. L. and PAINE, T. D. 1998. Effects of mycangial fungi and host tree species on progeny survival and emergence of Dendroctonus ponderosae (Coleoptera: Scolytidae). Environ. Entomol. 27:1393-1401.

SoKal, R. R. and RohlF, F. J. 1995. Biometry. W. H. Freeman, New York.

SolHEIM, H. 1992. The early stages of fungal invasion in Norway spruce infested by the bark beetle Ips typographus. Can. J. Bot. 70: 1-5.

SPRADBERRY, J. P. 1970. The biology of Ibalia drewseni Borries (Hymenoptera:Ibaliidae), a parasite of siricid woodwasps. Proc. R. Entomol. Soc. Lond. 45:104-1 13.

SPSS. 1997. SigmaStat ${ }^{\circledR} 2.0$ for Windows@ User's Manual. SPSS Inc., Chicago, IL.

Sullivan, B. T. 1997. The chemical ecology of host habitat location by larval parasitoids of the southern pine beetle, Dendroctonus frontalis Zimmermann: Olfactory cues and their possible sources. PhD Dissertation, University of Georgia, Athens, GA.

Sullivan, B. T., Berisford, C. W., and Dalusky, M. J. 1997. Field response of southern pine beetle parasitoids to some natural attractants. J. Chem. Ecol. 23:837-856.

Sullivan, B. T., Pettersson, E. M., Seltmann, K. C., and Berisford, C. W. 2000. Attraction of the bark beetle parasitoid Roptrocerusxylophagorum (Hymenoptera: Pteromalidae) to host-associated olfactory cues. Environ. Entomol. 29: 1138-I 151.

Sullivan, B. T., Seltmann, K. C., and BERISFord, C. W. 1999. A simple continuous-rearing technique for the bark beetle parasitoid, Roptrocerus xylophagorum(Ratzeburg). J. Entomol. Sci.34:260264.

Thibout, E., Guillot, J. F., and Auger, J. 1993. Microorganisms are involved in the production of volatile kairomones affecting the host seeking behaviour of Diadromus pulchellus, a parasitoid of Acrolepiopsis assectella. Phys. Entomol. 18:176-182. 
Upadhyay, H. P. 1981. A Monograph of Ceratocystis and Cerutocystiopsis. University of Georgia Press, Athens, GA.

VET, L. E. M., WÄCKERS, F. L., and DICKE, M. 1991. How to hunt for hiding hosts: The reliabilitydetectability problem in foraging parasitoids. Neth. J. Zool. 41:202-213.

Whitney, H. S. 1971. Association of Dendroctonus ponderosae (Coleoptera: Scolytidae) with blue stain fungi and yeasts during brood development in lodgeple pine. Can. Entomol. 103: 1495-1503.

YEARIAN, W. C., GOUger, R. J., and Wilkinson, R. C. 1972. Effects of the bluestain fungus, Ceratocystiopsis ips, on development of Ips bark beetles in pine bolts. Ann. Entomol. Soc. Am. $65: 481-487$. 